\title{
THE EFFECTS OF TYPE AND AMOUNT OF QUATERNARY SALTS ON MODIFICATION OF ÇANAKKALE BENTONITE
}

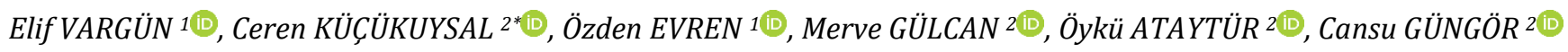 \\ 1 Department of Chemistry, Science Faculty, Muğla Sıtkı Koçman University, 48000, Muğla, Turkey \\ elifvargun@gmail.com, ozden1ev@hotmail.com, \\ 2 Department of Geological Engineering, Engineering Faculty, Muğla Sıtkı Koçman University,48000, Muğla, Turkey \\ cerenkucukuysal@mu.edu.tr, mervegulcn.93@gmail.com, ataytur6@gmail.com, cansugngrr@gmail.com
}

Received: 23.10.2017, Accepted: 11.12.2017

*Corresponding author

doi: $10.22531 /$ muglajsci.357263

\section{Abstract}

The improved dispersion of clay minerals has an essential role for polymer clay nanocomposite manufacturing. In this regard, different organomodifications of clay have been attempted to obtain intercalated/exfoliated structures of composites. In present study, Çanakkale bentonite was organically modified by four different quaternary ammonium salts: tetramethylammonium chloride (TMAC), hexadecylpyridinium chloride (HDPC), hexadecyltrimethylammonium bromide (HDAB), phenyltrimethylammonium chloride (PMAC). Fourier transform infrared spectroscopy (FTIR), X-ray diffraction (XRD) analysis and thermogravimetric analysis (TGA) were performed to characterize the organobentonites. The results revealed that there is an increment of basal spacing of bentonite with HDAB and HDPC salts from $14.9 \AA$ to $20.7 \AA$ and $21.4 \AA$, respectively. However, other modifiers cannot lead to significant changes in $d$-spacings.

Keywords: Polymer clay nanocomposite, organomodification, bentonite

\section{KUVATERNER TUZLARININ TÜRÜ VE MİKTARININ ÇANAKKALE BENTONITININ MODİFIKASYONU ÜZERINE ETKILERİ}

Öz

Kil minerallerinin düzgün dağılımı, polimer kil nanokompozit üretiminde önemli bir role sahiptir. Bu bakımdan, kompozitlerin interkale/eksfoliye yapılarını elde etmek için kilin farklı organomodifikasyon yöntemleri denenmiştir. Bu çalışsmada, Çanakkale bentonitinin tetrametilamonyum klorür (TMAC), hekzadesilpiridinyum klorür (HDPC), hekzadesiltrimetilamonyum bromür (HDAB), feniltrimetilamonyum klorür (PMAC) olmak üzere dörtfarklı kuvaterner amonyum tuzu ile organomodifikasyonu incelenmiștir. Organobentonitler Fourier transform infrared spektroskopi (FTIR), X-Ișını kırınım (XRD) analizi ve termogravimetrik analiz (TGA) ile karakterize edilmiștir. HDAB ve HDPC tuzları kullanılarak bentonitin bazal aralığı 14.9 A'dan sırasıyla 20.7 Å'a ve 21.4 A'a kadar artırılmıştır. Bununla birlikte, diğer modifiye edici tuzlar d-aralıklarında önemli değişikliklere neden olamamışlardır.

Anahtar kelimeler: Polimer kil nanokompozit, organomodifikasyon, bentonit

\section{Introduction}

The natural bentonite has been used widely to refer the clay rich deposits of volcanic origin and is associated with aqueous smectitic horizons [1]. Furthermore, the most commonly used definition was that "bentonites are the product of early diagenetic alteration of vitritic fallout ash by [2-4]. The dominant component of bentonites is the most expandable clays, smectites. Many recent studies have focused on polymer bentonite nanocomposites for different applications. Nanocomposites have been used as adsorbents and decoloration agents to remove heavy metals, phenols and other micro pollutants from water [5]. They are utilized as thickeners in paints and in oil drilling fluids [6,7]. They have better mechanical strength, dimensional stability, thermal stability, barrier and rheological properties compared with either polymer or clay alone $[8,9]$. Polymer clay nanocomposites involving organically modified montmorillonite also improved the ionic conductivity of the solid polymer electrolytes [10]. The abovementioned improved properties of nanocomposites can only be achieved by the intercalated and/or exfoliated morphologies of layered silicates. The reason clay agglomerates in the hydrophobic polymer matrix is that the hydrophilic nature of the clay minerals. In order to obtain nanoscale dispersion in polymer, hydrophilic clay layers should be converted lipophilic character and its surface energy should be lowered $[11,12]$. In general, chemical modifications such as grafting functional groups on to the clay surface or ion exchange with quaternary or tertiary alkyl ammonium / phosphonium based surfactants were employed [13]. The increment in the basal spacing of clay by modification with long alkyl chains results in a good compatibility with polymers. Modification may also lead to better diffusion of polymer chains into the galleries and delamination of silicate layers. Organomodification is based on ion exchange reaction between the interlayer cations $\left(\mathrm{Na}^{+}, \mathrm{K}^{+}, \mathrm{Ca}^{+2}\right.$, etc.) with the cations of organomodifiers.

Filho et. al. investigated organo modification of bentonite by cetyl trimethyl ammonium bromide and prepared nanocomposites with isotactic polypropylene by melt intercalation technique. They evaluated the effect of an organophilic bentonite on the thermal degradation of polypropylene and found that the modified bentonite had higher thermal stability than the natural clay [14]. Seyidoglu et. al. modified montmorillonite rich local bentonite with four different quaternary ammonium and phosphonium salts. Organoclays were characterized by Fourier transform infrared spectroscopy (FTIR), thermogravimetric analysis (TGA), and $\mathrm{x}$ - 
ray diffraction (XRD) analysis. The increased basal spacings of the bentonite after modification indicates intercalation and mechanical properties of PP have been enhanced by incorporating organoclay (modification and characterization of bentonite) [15]. High exfoliation level in organomontmorillonite/polyurethane nanocomposites resulted in higher tensile modulus, stress at break and lower deformability (elongation at break) [16].

In the present work, the modification of Çanakkale bentonite was investigated for potential use in polymer clay nanocomposite production. Four different quaternary alkyl ammonium salts were examined and the effects of the concentrations and alkyl chain length of salts on modification of bentonite were evaluated. The chemical structures and $d$ spacings of organobentonites were determined by Fourier transform infrared spectroscopy (FTIR) and X-ray diffraction (XRD) analysis. Thermal stabilities of organobentonites were also investigated by thermogravimetric analysis (TGA).

\section{Experimental}

\subsection{Materials}

Na-hexametaphosphate (96\%, Sigma), methylene blue (Merck), tetramethylammonium chloride (98\%, Sigma), hexadecylpyridinium chloride $\quad(99 \%, \quad$ Sigma), hexadecyltrimethylammonium bromide (98\%, Sigma), phenyltrimethylammonium chloride (99\%, Merck) were used as received. The chemical structures of ammonium salts were given in Table1.

\subsection{Separation of fine fraction}

Separation of clay size fraction was an essential component of purification of bentonite. Sample preparation was completed in Clay Mineralogy Laboratory of Mugla Sitki Kocman University following the combined methods of [17-20]. The bulk sample was disaggregated gently with agate pestle and mortar. Then, the disaggregated samples were placed in a $600 \mathrm{ml}$ beaker, filled with distilled water. Then, it was mixed with a magnetic stirrer for two minutes by adding $3 \mathrm{mg}$ of $\mathrm{Na}$ hexametaphosphate to avoid the flocculation. Then, the slurry was left for approximately 22 hours (room temperature $22{ }^{\circ} \mathrm{C}$ according to Stoke's Law. The supernate of fine fraction was then siphonned into a $250 \mathrm{ml}$ beaker. The supernate was finally poured off into six falcon tubes and centrifuged for 10 minutes at $10000 \mathrm{rpm}$. At the end of the run, the clean water and clay was separated. The clay fraction was collected in a smaller beaker and dried out in the oven at $60^{\circ} \mathrm{C}$ overnight.

\subsection{Determination of Cation Exchange Capacity}

The method of [21] was followed in Methylene Blue (MB) solution preparation and in determination of cation exchange capacity of the fine fraction of the bentonite sample. 3gr of methylene blue is weighed and mixed with $300 \mathrm{cc}$ distilled water by magnetic stirrer for 3 minutes. At the same time, the fine fraction of the bentonite sample was powdered by agate pastle and mortar and then weighed as $7.5 \mathrm{~g}$, mixed with $50 \mathrm{cc}$ distilled water by magnetic stirrer.
Table1. Structure of ammonium salts and abbreviations of organobentonites

\begin{tabular}{|l|l|l|l|}
\hline Ammonium Salts & $\begin{array}{l}\text { Chemical Structures of } \\
\text { Salts }\end{array}$ & Abbr. \\
\hline $\begin{array}{l}\text { Tetramethyl } \\
\text { ammonium chloride }\end{array}$ &
\end{tabular}

Methylene blue solution was placed in a brute that was fixed at vertical position over the beaker containing clay-water mixture. 1cc methylene blue was added to the bentonite-water mixture and mixed continuously by magnetic stirrer for 1 minute. A droplet was taken from the MB added bentonitewater mixture with the help of a glass pipette and placed on a filter paper. This procedure continued till the white halo around the dark blue droplet became light blue colored which shows that the substitution of the cations between the methylene blue and montmorillonite was completed. Cation Exchange Capacity (CEC) of the fine fraction of bentonite was calculated with the provided formula (1) [22].

$$
\begin{array}{rl}
(\text { C. E. C. })=100 / \mathrm{f} & * \text { Vcc } * \text { NMB } \\
& =(\mathrm{meq} / 100 \mathrm{gr})(1) f(x)
\end{array}
$$

where f stands for dry weight of clay sample (7.5 gr), Vcc is the amount of methylene blue diluted added to clay sample, NMB is the normality of the MB solution (standard $=0.028$ ).

\subsection{Modification}

Typically, $1 \mathrm{~g}$ raw bentonite was dispersed in $100 \mathrm{~mL}$ deionized water and the mixture was stirred for $24 \mathrm{~h}$ by magnetic stirrer at ambient temperature. The bentonite/water suspension was poured into a 3-necked flask with condenser, thermocouple and dropping funnel. Then the flask was heated to $65^{\circ} \mathrm{C}$ in oil bath. $0.7 \mathrm{xCEC}$ of the ammonium salt was dissolved in $100 \mathrm{~mL}$ deionized water and added slowly to the bentonite/water suspension by dropping funnel. Separately, 1.4xCEC and 2.1xCEC of ammonium salts were also examined to understand the effect of the amount of salts on basal spacing increment. The cation exchange reaction was maintained at $65^{\circ} \mathrm{C}$ for 4 hours by a magnetic stirrer and then the flask was cooled to ambient temperature. The solution was centrifuged at $4000 \mathrm{rpm}$ for 15 min. and the modified bentonite was then washed with deionized water for four times by centrifuge. The product was dried at $55^{\circ} \mathrm{C}$ in a vacuum oven and stored in a desiccator. 


\subsection{Characterization}

FTIR spectra of the raw bentonite and organomodified bentonites were acquired on Thermo Scientific Nicolet is 50 with a number of scan 32 and resolution $16 \mathrm{~cm}^{-1}$ within 4000 $400 \mathrm{~cm}^{-1}$ range. For characterization of the natural bentonite, mineralogical analysis was first conducted by the $x$-ray diffractometer. The powder mounts of the bulk dried bentonite sample was ground gently, placed in a sample holder and scanned using Panalytical Expert Pro diffractometer with a $\mathrm{Cu}$ tube at $40 \mathrm{kV}$ voltage and $30 \mathrm{~mA}$ current. The diffractogram was plotted between $4^{\circ}-70^{\circ} 2 \theta$ with a scanning rate of $2^{\circ} / \mathrm{min}$. Qualitative determinations of the minerals were based on [23, 19]. The minerals in the clay size fraction were determined by operating Rigaku Diffractometer equipped with a $\mathrm{Cu}$ tube at $40 \mathrm{kV}$ voltage and $30 \mathrm{~mA}$ current. The diffactograms of the claysize sample were plotted between $2^{\circ}-82^{\circ} 2 \theta$ with a scanning rate of $2^{\circ} / \mathrm{min}$. Thermal stabilities and decomposition temperatures of samples were determined by Perkin Elmer TGA 4000 analyzer within $35^{\circ}-850^{\circ} \mathrm{C}$ under nitrogen atmosphere. 5-10 mg samples were heated with $10^{\circ} \mathrm{C} / \mathrm{min}$ rate and $\%$ weight losses vs. temperature thermograms were obtained.

\section{Results and Discussion}

The CEC of raw bentonite was found as $45.5 \mathrm{meg} / 100 \mathrm{~g}$. Four different quaternary salts were used in various percentages of CEC $(0.7,1.4$ and 2.1) and then, modified bentonites were characterized by different methods.

\subsection{FTIR Analysis}

FTIR spectrum of raw bentonite revealed the characteristics bands and given in Figure 1. The peak at $3620 \mathrm{~cm}^{-1}$ is associated with $-\mathrm{OH}$ stretching and the band at $1634 \mathrm{~cm}^{-1}$ is attributed to $-\mathrm{OH}$ bending. The strong peak at $1014 \mathrm{~cm}^{-1}$ shows Si-O stretching and $\mathrm{Al}-\mathrm{OH}$ deformation and $\mathrm{AlFe}-\mathrm{OH}$ vibrations can be seen clearly at $912 \mathrm{~cm}^{-1}$ and $792 \mathrm{~cm}^{-1}$, respectively. After the organomodification of bentonite with hexadecyltrimethyl ammonium bromide (HDAB) a pair of bands between 2921 and $2845 \mathrm{~cm}^{-1}$, which result from asymmetric and symmetric $\mathrm{C}-\mathrm{H}$ stretching of the $\mathrm{CH}_{3}$ and $\mathrm{CH}_{2}$ groups appeared newly in Figure 1. FTIR spectra of HDAB modified bentonite also depict a peak at $1469 \mathrm{~cm}-1$ which can be assigned as flexural vibrations of $\mathrm{CH}_{3}$ (Fig. 1a) [24].

Figure $1 \mathrm{~b}$ and $1 \mathrm{c}$ represent the FTIR spectra of modified bentonite with phenyltrimethylammonium chloride (PMAC) and tetramethylammonium chloride (TMAC), respectively. Comparison of the spectra shows the presence of the same peaks in all samples, indicates that the structure of the bentonite samples was maintained after PMAC and TMAC treatment. Hence, the salt molecules cannot be incorporated into the galleries of bentonites.

Figure 1d displays the FTIR spectra of organobentonites modified with hexadecylpyridinium chloride (HDPC) and both clay and modifier related peaks can be identified. The bands at 2926 and $2846 \mathrm{~cm}^{-1}$ represent the symmetric and asymmetric $\mathrm{C}-\mathrm{H}$ stretching of $\mathrm{CH}_{2}$ groups. Also the peak at $1481 \mathrm{~cm}^{-1}$ corresponds to the $\mathrm{C}-\mathrm{H}$ bending of long alkyl groups. These results indicate the intercalation of HDPC within the bentonite layers and this effect can be seen as more intense peak in FTIR spectra of modified bentonites from $0.7 \times C E C$ to $2.1 \times C E C$ modifier ratios.

\subsection{XRD Analysis}

The $<2 \mu \mathrm{m}$ size fraction includes montmorillonite, illite, cristobalite and calcite (Fig. 2). Montmorillonite shows the highest peak of $14.91 \AA$ at $5.92^{\circ} 2 \theta$. Very weak reflection of illite $\mathrm{d}(001)$ at $10 \AA$ and relatively intense $\mathrm{d}(002)$ at $5 \AA$ were observed. Intense cristobalite peak (4.04 $\AA$ ) and weak calcite peak ( $3.03 \AA$ ) were seen in the clay fraction.

XRD data of raw bentonite and organobentonite were given in Table 2. XRD of organically modified betonite with 0.7 HDAB shows that the montmorillonite peak shifted to smaller two theta angle and the $d$ spacing value increased up to $15.18 \AA$. The nonclays remain at the same angles with the same reflections. The increment of salt as 1.4 HDAB resulted in increased dspacing of montmorillonite to $20.58 \AA$ at $4.29^{\circ} 2 \theta$. When the concentration of salt was $2.1 \mathrm{HDAB}$, bentonite sample did not create significant difference from 1.4HDAB modification (Fig. 2).

The second and third modifiers were PMAC and TMAC, respectively (Table 2). Both, PMAC and TMAC organomodification did not cause expansion in basal spacing of bentonite (Fig. 2). For TMAC modifier, short alkyl chain length is not enough to increase the $\mathrm{d}$-spacing, therefore the incorporation of the salt into the gallery of the bentonite did not occur.

The final organomodification was tried by HDPC (Table 2). The maximum unit thickness values were observed by 1.4 and 2.1 HDPC ratios as $20.39 \AA$ at $4.34^{\circ} 2 \theta$ and as $21.43 \AA$ at $4.12^{\circ} 2 \theta$, respectively (Fig. 2). XRD characterizations show that the organomodification of bentonite was successful just for HDAB and HDPC ammonium salts.

\subsection{TGA Study}

Thermal stabilities of the raw bentonite and modified bentonites were determined by thermogravimetric analysis (TGA) (Fig. 3-6). The decomposition temperatures and char yields of the samples were tabulated in Table 2. TGA data revealed that the initial weight loss (T1) at around $90^{\circ} \mathrm{C}$ can be attributed to evaporation of adsorbed water. The second weight loss (T3) was observed at $657^{\circ} \mathrm{C}$ and is reflected with the equivalent endothermic peak due to dehydroxylation of bentonite [25]. Raw bentonite was thermooxidatively stable up to $850^{\circ} \mathrm{C}$ and only $15 \%$ of weight of raw bentonite was lost at this temperature (Fig. 3-6). For organomodified bentonites one or two degradation stages were added due to the decomposition of intercalated alkyl tails of the salts in the range of $323-454{ }^{\circ} \mathrm{C}$ (Fig. 3-6). It was also found that organically modified bentonites have lower percent char yield than that of raw bentonite and the value decreases with increasing salt content in modification. This effect can be clearly seen in organobentonites which modified with HDAB and HDPC salts (Fig. 3 and 6). Besides, TGA analysis showed that PMAC and TMAC salts modified bentonites have less residual char which indicates less organic content present in the organobentonites (Fig. 4 and 5). 


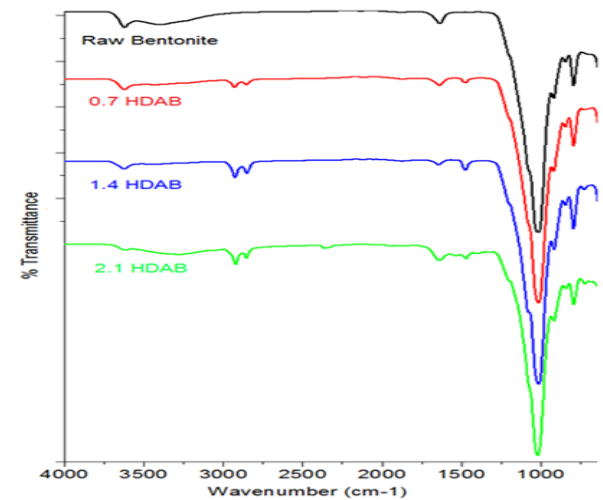

(a)



(c)

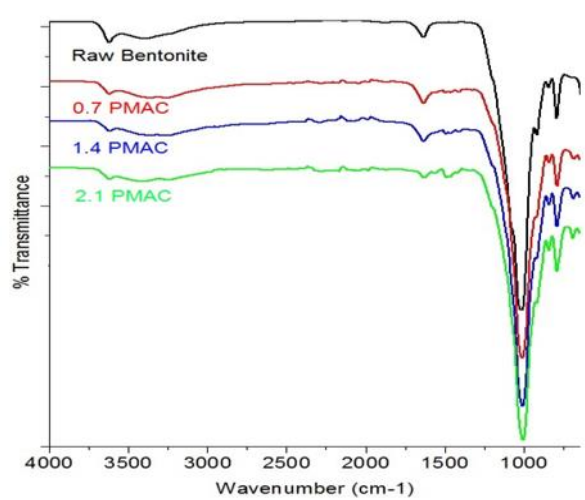

(b)

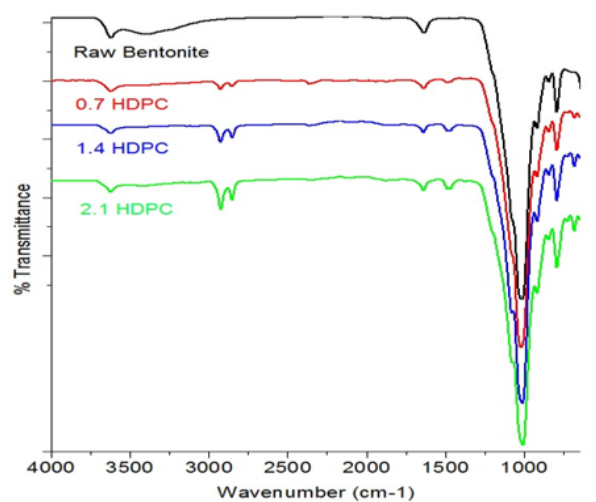

(d)

Figure 1. FTIR spectra of raw bentonite and organobentonites modified with a) hexadecyltrimethyl ammonium bromide (HDAB); b) phenyltrimethylammonium chloride (PMAC); c) tetramethylammonium chloride (TMAC); d) hexadecylpyridinium chloride (HDPC)

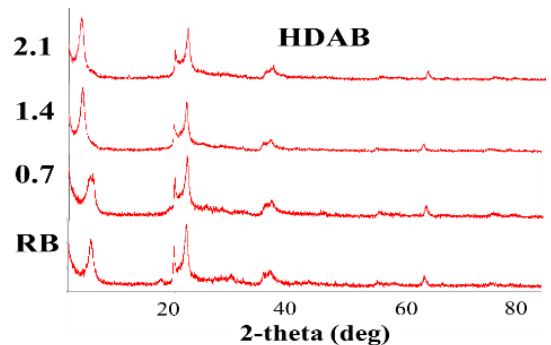

(a)

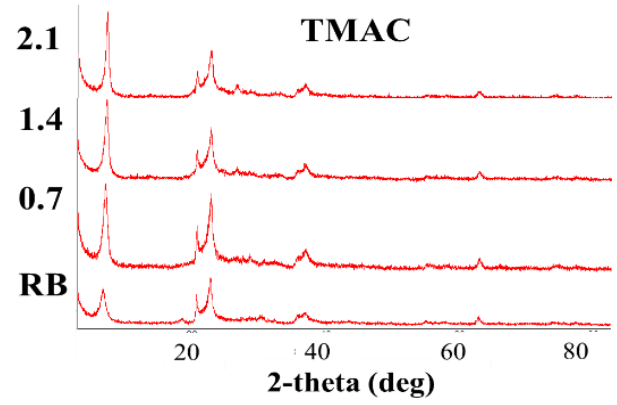

(c)

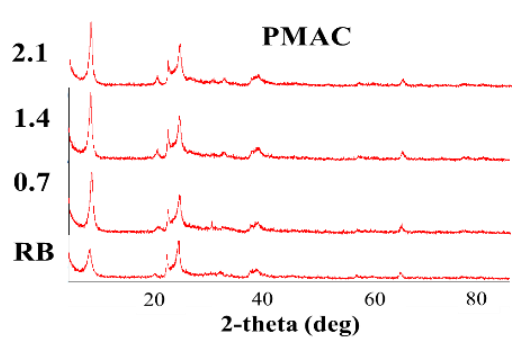

(b)

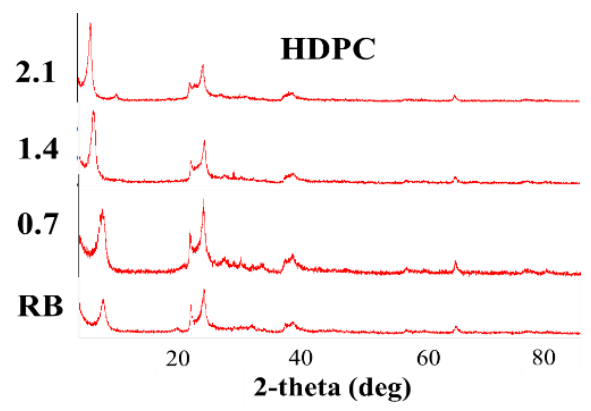

(d)

Figure 2. X-ray diffractograms of fine fraction bentonite (RB) and organomodified bentonites 


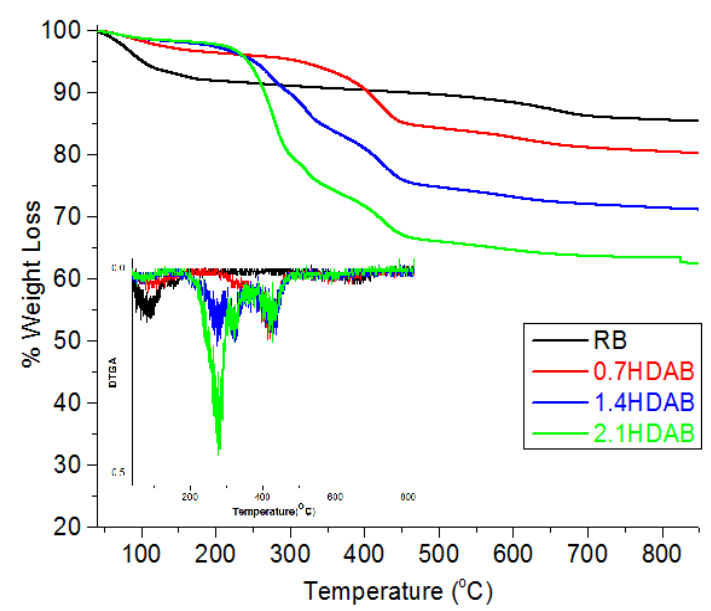

Figure 3. TGA and DTGA thermograms of raw bentonite and organobentonites modified with hexadecyltrimethyl ammonium bromide

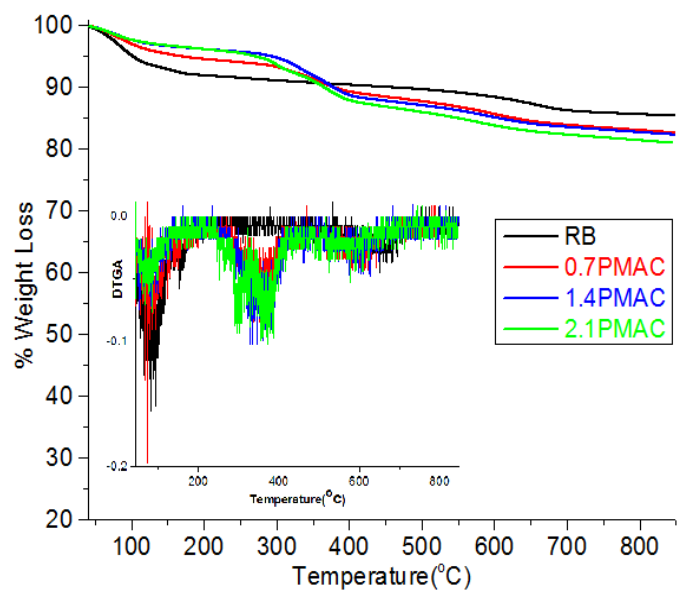

Figure 4. TGA and DTGA thermograms of raw bentonite and organobentonites modified with phenyltrimethyl ammonium chloride



Figure 5. TGA and DTGA thermograms of raw bentonite and organobentonites modified tetramethylammonium chloride

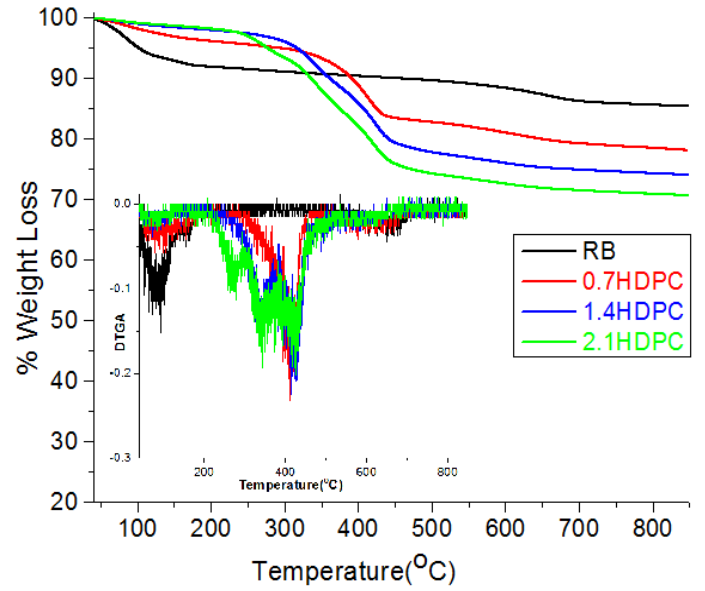

Figure 6. TGA and DTGA thermograms of raw bentonite and organobentonites modified with hexadecylpyridinium chloride

\section{Conclusion}

The effect of different ammonium salts on the intercalation with the bentonite sample was evaluated by XRD, FTIR and TGA analyses. XRD results clearly present the increment in the basal spacings of bentonite by HDAB and HDPC salts. FTIR analyses also confirm the intercalation with the same salts in that new absorption bands appear after modification. Furthermore, new degradation stages of bentonite on TGA showed the decomposition of the intercalated alkyl tails of HDAB and HDPC salts. Consequently, it can be concluded that HDAB and HDPC salts modified the bentonite sample to be used in further polymer clay nanocomposities, whereas, PMAC and TMAC salts were determined insufficient for the intercalation.

Table 2. TGA Data for raw bentonite and organobentonites

\begin{tabular}{|l|l|l|l|l|l|l|}
\hline $\begin{array}{l}\text { Sample } \\
\text { Code }\end{array}$ & $\begin{array}{l}\mathrm{T}_{1} \\
\left({ }^{\circ} \mathrm{C}\right)\end{array}$ & $\begin{array}{l}\mathrm{T}_{2} \\
\left({ }^{\circ} \mathrm{C}\right)\end{array}$ & $\begin{array}{l}\mathrm{T}_{3} \\
\left({ }^{\circ} \mathrm{C}\right)\end{array}$ & $\begin{array}{l}\text { Char } \\
\text { yield at } \\
850^{\circ} \mathrm{C}\end{array}$ & $\mathrm{d}(\AA)$ & $2 \theta$ \\
\hline Raw Bent & 92 & - & 657 & 85.4 & 14.91 & 5.92 \\
\hline $0.7 \mathrm{HDAB}$ & 97 & 423 & 635 & 80.2 & 15.18 & 5.82 \\
\hline 1.4HDAB & - & 323 & 601 & 71.2 & 20.58 & 4.29 \\
\hline 2.1HDAB & - & 323 & 600 & 62.5 & 20.72 & 4.26 \\
\hline $0.7 \mathrm{PMAC}$ & 89 & 356 & 602 & 82.6 & 14.41 & 6.12 \\
\hline 1.4PMAC & 87 & 379 & 601 & 82.3 & 14.88 & 5.93 \\
\hline 2.1PMAC & 79 & 373 & 590 & 80.9 & 14.95 & 5.90 \\
\hline $0.7 \mathrm{TMAC}$ & 92 & 431 & 626 & 84.5 & 14.36 & 6.14 \\
\hline 1.4TMAC & 86 & 447 & 620 & 84.6 & 13.81 & 6.39 \\
\hline 2.1TMAC & 80 & 454 & 611 & 82.1 & 14.02 & 6.30 \\
\hline $0.7 \mathrm{HDPC}$ & 90 & 414 & 624 & 78.2 & 14.92 & 5.91 \\
\hline 1.4HDPC & 84 & 339 & 615 & 74.1 & 20.34 & 4.31 \\
\hline 2.1HDPC & 83 & 345 & 607 & 70.7 & 21.43 & 4.11 \\
\hline
\end{tabular}




\section{Acknowledgment}

This study was financially supported by Mugla Sitki Kocman University with BAP 17/011 project number. Part of this study was presented in 17th National Clay Symposium, 2017.

\section{References}

[1] Chamley, H., "Clay Sedimentology", Springer, Verlang Berlin Heildeberg Newyork, 626p., 1989.

[2] Millot, G., "Geology of Clays. Weathering, Sedimentology, Geochemistry", Springer, Paris, 443p., 1970.

[3] Grim, R. and Guven, N., "Bentonite: Geology, Clay Mineralogy Properties and Users", Elsevier Science Publishing, New York, 1978.

[4] Fisher, R.V. and Schmincke, J.U., "Pyroclastic Rock", Springer-Verlag, Berlin, 1984

http://dx.doi.org/10.1007/978-3-642-74864-6

[5] Unuabonah, E. I. and Taubert, A., "Clay-polymer nanocomposites (CPNs): Adsorbents of the future for water treatment", Applied Clay Science, 99, 83-92, 2014.

[6] Yamada, H., Tamura, K., Watanabe, Y., Iyi, N. and Morimoto, K., "Geomaterials: their application to environmental remediation", Science and Technology of Advanced Materials, 12, 064705, 1-13, 2011.

[7] Kloprogge, J.T., "Synthesis of Smectites and Porous Pillared Clay Catalysts: A Review", Journal of Porous Materials, 5, 5-41, 1998.

[8] Scocchi, G., Posocco, P., Fermeglia, M. and Pricl, S., "Polymer-clay nanocomposites: a multiscale molecular modeling approach", The Journal of Physical Chemistry B, 111, 2143-2151, 2007.

[9] Jash, P. and Wilkie, C.A., "Effects of surfactants on the thermal and fire properties of poly(methyl methacrylate)/clay nanocomposites", Polymer Degradation and Stability, 88, 401-6, 2005.

[10] Sivaraman, P., Shashidhara, K., Thakur, A.P., Samui, A.B. and Bhattacharyya, A.R., "Nanocomposite Solid Polymer Electrolytes Based on Polyethylene Oxide, Modified Nanoclay, and Tetraethylammonium Tetrafluoroborate for Application in Solid-State Supercapacitor", Polymer Engineering and Science, 1536-1545, 2015.

[11] Ying, Z., Xianggao, L., Bin, C., Fei, C. and Jing, F., "Highly exfoliated epoxy/clay nanocomposites: Mechanism of exfoliation and thermal/mechanical properties", Composite Structures, 132, 44-49, 2015.

[12] Sinha, R.S. and Okamoto, M., "Polymer/layered silicate nanocomposites: a review from preparation to processing", Progress in Polymer Science, 28, 1539-1641, 2003.

[13] Kotal, M. and Bhowmick, A.K., "Polymer nanocomposites from modified clays: Recentadvances and challenges", Progress in Polymer Science, 51, 127-187, 2015.

[14] Filho, F.G.R., Mélo, T.J.A., Rabello, M.S. and Silva, S.M.L., "Thermal stability ofnanocomposites based on polypropylene and bentonite", Polymer Degradation and Stability, 89, 383-92, 2005.

[15] Seyidoglu, T. and Yilmazer, U., "Modification and characterization of bentonite with quaternary ammonium and phosphonium salts and its use in polypropylene nanocomposites", Journal of Thermoplastic Composite Materials, 28(1), 86-110, 2015.

[16] Taheri, S. and Sadeghi, G.M.M., "Microstructure-property relationships of organo-montmorillonite/ polyurethane nanocomposites: Influence of hard segment content", Applied Clay Science, 114, 430-439, 2015.

[17] Brindley, G.W., "Quantitative X-ray analyses of clays. In: Brindley, G.W. and Brown, G. (eds), Crystal Structures of Clay Minerals and Their X-ray Identification", Mineralogical Society Monograph 5, 411-438, 1980.

[18] Jackson, M.L., Soil chemical anaylsis-advaced course, 2nd edition. Published by the author, Madison, Wisconsin, U.S.A., 895p., 1979.

[19] Thorez, J. "Practical Identification of Clay Minerals", Lelotte, Dison, Belgium, 42, 1976.

[20] Tucker, M., "Techniques in sedimentology", Oxford: Blackwell Scientific Publications, 394p., 1988.

[21] Jones, F.O., "New fast accurate test measures bentonite in drilling mud", Oil \& Gas Journal, June, 76- 78, 1964.

[22] Çokca, E., Birand, A.A., "Determination of cation Exchange capacity of clayley soils by the methylne blue test Geotechnical Testing journal", GTJODJ 16(4), 518-524, 1993.

[23] Moore, D.M. and Reynolds, J.R. "X-ray Diffraction and the Identification and Analysis of Clay Minerals", Oxford University Press, Oxford, 1989.

[24] Junior, C. A. L., Silva, D. S. A., Filho, A. P. da C., Lucas, E. F., Santana S. A. A. "Smectite Clay Modified with Quaternary Ammonium as Oil Remover", J. Braz. Chem. Soc., 28(2), 208-216, 2017.

[25] Mielenz, R.C., Schieltz, N.C., and King, M.E. "Thermogravimetric analysis of clay and clay-like minerals", Clays and Clay Minerals, 2, 285-314, 1953. 